\title{
Ecolinguistic Types of Traditional House Building at the Southern Border of Central Java as Javanese Sociocultural Equality
}

\author{
Riris Tiani $^{{ }^{*}}, M$. Suryadi ${ }^{2}$ \\ ${ }^{1}$ Faculty of Humanities, Diponegoro University, Semarang - Indonesia \\ ${ }^{2}$ Faculty of Humanities, Diponegoro University, Semarang - Indonesia
}

\begin{abstract}
People of southern coastal border of Central Java have extraordinary features, not only biological ecology, but also ecolinguistic features that can be seen from the socio-cultural awareness community. Socio-cultural awareness of people the southern coastal border Central Java is reflected in behavior of simplicity and openness with the ecology of their immediate environment. These two things are the reflection of solidarity upheld by the community. Their closeness to nature forms the character of society full of symbolic values. This research examines the philosophical meaning and local wisdom functions of the architecture of traditional house building of people at the southern coastal border of Central Java. The orientation of this research is to interpret the form of ecological acculturation reflected in the traditional house buildings of southern coastal border communities of Central Java. This research constitutes a qualitative type with contextual descriptive method. In answering socio-cultural problems, ecolinguistics and cultural anthropology were used as the basis of this research analysis. The results of this study indicate the unitary environmental orientation of the basic concept for the construction of traditional houses in the southern coastal community of Central Java, spiritual orientation counterweighting the strength of traditional house buildings, and economic orientation as the form of togetherness and openness of the southern coastal communities Central Java.
\end{abstract}

\section{Introduction}

Natural Natural disasters can occur suddenly or gradually. Earthquakes are natural disasters that can hardly be predicted accurately in terms of time, location, and magnitude. Unlike landslides, volcanic eruptions and drought can be predicted before. Any disaster is likely to inflict casualties and material losses. Humans should be alert to minimize them.

The Southern Coast of Central Java directly borders the Indian Ocean. The ecology of the community relies heavily on the natural environment. This reliance makes them worship nature [1]. It has developed into local wisdom. The long history of the Majapahit Kingdom has made them uphold cultural values. The tradition followed shapes local wisdom, local knowledge, and the local genius of the local community [2]. Local wisdom is shaped from the long experiences becoming convention and guidance for the community so that they are not separated from their natural environment. [3]. One of the essences of local wisdom is the guard or filter of the global climate engulfing the human's life which is often contrary to the natural environment. Local wisdom is the knowledge people have acquired through accumulations of experiences when trailed and integrated with the understanding of 
surrounding nature and culture [4]. Local wisdom is dynamic and very connected to the natural environment.

Local wisdom is pervasive and comprehensive. It cannot be limited by space due to its connection with the convention, which becomes the guidance in harmonisation with nature. Local wisdom emphasises places and localities, so it is not always tradition passed from generation to generation. It can emerge from cultural acculturation naturally due to the results of the interaction between humans and their environment. Local wisdom can be interpreted as the culture of a community which they take as a worldview. Local wisdom is a part of the culture and can be viewed as a tradition related to farming activities, livestock, and house building [5]. Local communities know that they have traditionally inherited in protecting the nature and environment [6].

Local wisdom is classified into intangible and tangible ones. The intangible local wisdom is wise notions to build characteristics and prepare better life for noble humans. In contrast, physical and symbolic wisdom can remind or show past events to be better humans. The physical dimension can be traditional ceremonies, attire, folklore, symbols of vegetation, and vernacular architecture. This study is aimed to reveal the philosophical meaning and function of local wisdom in the vernacular architecture of the people in Cilacap, reflecting the harmonization with the natural environment.

\section{Research Method/Research Methodology}

This is qualitative research on the philosophical meaning and the function of local wisdom in the vernacular architecture of the southern coastal community in Central Java, especially Cilacap. The phenomenological contextual descriptive approach was used to analyze. In addition, cultural anthropology and ecolinguistics were used to reveal the philosophical meaning and function of the locals in the architecture to find the innovative model of the development and preservation of local identity in terms of the authentic local wisdom of the vernacular architecture.

This research was conducted on the southern coast of Central Java bordering West Java, particularly Cilacap, bordering the Indian Ocean, and constituting the chain of the past and oldest civilization in Central Java, where Majapahit once existed. Geographically, Cilacap is the border between two big provinces: Central Java and West Java. It is believed to have very high acculturation having considerable influence on the local identity of its people, reflected in the vernacular architecture. In detail, Cilacap has wealthy local wisdom, one of which is the vernacular architecture similar to that of West Java. Furthermore, all houses rely on the natural environment. Due to the history of the great kingdom, the people are under the influence of Javanese spiritual power and, therefore, have a unique culture.

\section{Result and Discussion}

Local wisdom is closely related to the Javanese worldview. It is very philosophical and has deep spiritual functions. It shapes very religious moral behaviour and ethics, which harmonize life spirituality with the universe.

\subsection{The Philosophical Meaning of the Vernacular Architecture}

The traditional houses in Cilacap are similar to the other Javanese ones. The similarities are the forms and philosophical meaning due to the location of Cilacap in Central Java near West Java. 
The people of Cilacap call their traditional houses Bandung Tikelan. Etymologically, Bandung is derived from the word bandungan, which means houses united into a big house. On the other hand, tikelan comes from the word tikal, which means "double". Bandung Tikalan is conventionally known as two houses united into a big majestic house with nipah leaves as its roof.

The vernacular architecture of the traditional house of Bandung Tikalan consists of two main buildings, i.e. pendhapa (a pavilion) and dalem. The façade constitutes a very large pendhapa, even more, significant than the main house. Pendhapa is an open façade without partitions and walls. There are four main posts (soko) inside made of fine teak. It is used as it has philosophical meaning as the manifestation of the heart or soul. Four souls are unified (husband-wife and in-laws). Even though they do not live under the same roof, their nobility and modesty must stand tall in keeping the household.

The architecture of pendhapa is different from that of the main house or dalem. Pendhapa has lower roofs than those of the main house. Etymologically, pendhapa is derived from the word andhap, which means "modest", and has a philosophical meaning that anyone who comes to and leaves a house should let go of all worldly affairs or egos to have a quiet soul. A house is believed to protect against the disorder of the outside world. It is reflected by padhusan or a water fountain beside the façade. Anyone who will enter the house must let go of emotion and bad luck in his or her body by splashing clean water onto his or her face, hands, and feet.

The pendhapa is made large to gather for relatives, neighbours, religious leaders, and religious rituals. This characteristic is very dominant among the coastal communities, who are very open and believe in mystical forces. It is the manifestation of their unity with the natural environment. The simplicity of natural building materials follows the openness. A house has special meaning for the Javanese family as the symbol of their culture and intermediary of their unity with God, the final destination of human life. Abeer researched the traditional houses in Jeddah called Rowshan, concluding that Rowshan relies heavily on nature [7]. Rowshan uses the sunlight as the main daylighting. It minimizes the need for artificial lighting and accumulates the sunlight more effectively. Its most significant use is to reduce the use of energy and disperse the sunlight directly into the house. Today, it has developed into eco-friendly control [7].

The Javanese ethics have philosophical meaning in terms of behaviour, action, selfawareness, and appropriate life concept, as illustrated by picture 1. The philosophical meaning inspires the foundation of traditional houses, particularly in their facing directions.

The philosophical concept of the coastal community is as follows:

a. east, reflected by the symbol of the white light as the manifestation of the light of life or source of life which has the philosophical meaning of the symbol of the owner's authority,

b. west, reflected by the symbol of the yellow light as the manifestation of death with the philosophical meaning of disasters or catastrophes,

c. north, reflected by the symbol of the black light with the philosophical meaning of the hop giver or helper under physical and emotional circumstances,

d. south, reflected by the symbol of the red light with the philosophical meaning of the great spirit, toughness, and strength, when the owner faces disasters. 


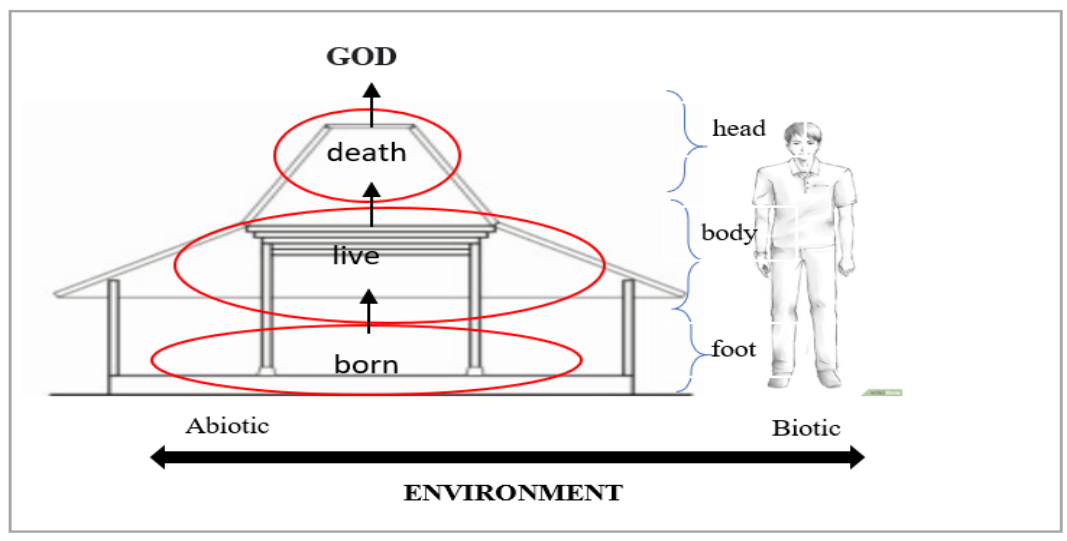

Picture 1. The Symbolic Hierarchy of Traditional House Bandung Tikelan

\subsection{The Functions of Local Wisdom in Its Intangible and Tangible Dimensions}

The forms of local wisdom in the coastal culture in the intangible dimension are reflected in the notion or thought of being better humans, as can be found in Javanese wise advice. One of the Pitutur luhur is "manawa sira urip aneng gisik, sira kudu nglilakna manawa niyunge njaluk bali maneh yogane" (if you live on the coast, you must accept if the mother wants her children back). In addition, there are other forms of local wisdom, such as ethics or conventional norms, rituals, traditional houses, traditional clothing, local languages, and traditional food [5]. The cultural elements can be local genius and must survive through the ages, not influenced by foreign culture although the community is dynamic and open, flexible about the foreign culture, and can control the cultural development socially and morally.

Local wisdom for the southern coastal community is considered to be the life guidance full of religious experiences. They are beliefs and devotion to God as the system of beliefs, inspiring humans in virtue. It makes the community tend to accept simplicity. Simplicity is a human's spiritual attitude to be in harmony with the natural environment.

Local wisdom for them also has the functions of natural conservation, knowledge as the self-control over the cultural development coming from the God, symbolic advice given from generation to generation as the self-control over the harmonization with other humans. In response to the forms of local wisdom, the coastal community also has wise views. Firstly, local wisdom is seen as the mystical belief that self-knowledge is a supernatural belief that cannot be explained using common sense. Secondly, the ontological belief implies that there is a distance between humans and the world. It is reflected in the hierarchy of vernacular architecture, where there are three life processes that humans go through before returning to God. Thirdly, the functional belief implies that humans must be aware of making good use of nature. The natural resources support sustainable life so that they must be used sufficiently and may not be misused. This view makes the coastal community rely on natural harmonization.

\section{Conclusion}

The vernacular architecture of the coastal community has a long history. The layout, the designs of pendhapa and omah dalem have very noble philosophical meanings and functions. The noble character of the community pesisir is reflected in their essential character-defining 
them. Intelligence, openness, and simplicity are the primary characters representing the majesty of the natural environment. The philosophical meaning and functions of the architecture of Bandung Tikalan are full of religious symbols showing the harmonization with nature. The use of building materials like wood leaves as the roofs, the absence of partitions and glass windows let sunlight indirectly be the natural lighting in the house. The maximum lighting minimizes the use of the artificial one, constituting the coastal community's high intelligence. Therefore, Bandung Tikalan can be developed into traditional eco-friendly houses.

\section{Reference}

1. Philip, Boland. Sonic Geography, Place and Race in The Formation of Local Identity: Liverpool and Scousers. (2020) http://www.jstor.com/stable/40835383

2. Tiani, Riris. Preservation of Cultural Identity through Speech Components in the Southern Coastal Java Environment. (2020).

https://doi.org/10.1051/e3sconf/202020207045

3. Suryadi \& Riris Tiani. The Influence of The Richness of Emotive Cultural Lexicon in Coloring The Politeness Form of Speech and Politeness Gradation of The Coastal Javanese Society in Pati District E3S web of conferences 73. (2018) https://doi.org/10.1051/e3sconf/20187308023

4. Naritoom, Chatcharee. Local Wisdom Indegegenous Kwonledge System. Nakhon Pantom, Thailand: Kaseysart University. (2011).

5. Greetz. The Interpretation of Cultures. New York: Basic Books, Ins, Publisher. (1973)

6. Rozi, Syafwan. Adaptation of Religion and Local Wisdom in Global Environmental Issues in Indonesia. (2020). https://doi.org/10.15575/rjsalb.v4i3.9593

7. Abeer, Alawad. Using the Architectural Style of Heritage Buildings as a tool to Avoid Health Risk An Analytical Study of Rowshan in traditional houses in the city of Jeddah. (2017). https://doi.org/10.1016/j.proenv.2017.03.047 